\title{
PICLORAM GRANULES FOR WOODY WEED CONTROL
}

\author{
R. W. MOFFat \\ Ivon Watkins-Dow Ltd., New Plymouth
}

\begin{abstract}
Summary
Investigations with granular formulations of picloram on sweet brier (Rosa rubiginosa), gorse (Ulex europaeus), blackberry (Rubus fruticosus), broom (Cytisus scoparius) and ragwort (Senecio jacobaea) are reviewed. Picloram has shown a high level of activity against these weeds, the granular formulation giving at least equal results to those obtained when applied as a toliage spray. Factors affecting the efficiency of granule applications and the place of granular herbicides in a weed control programme are discussed.
\end{abstract}

\section{INTRODUCTION}

THE USE of granular herbicides for scrub weed control is not a new concept. However, at present the availability and usage of spray formulations far outweigh that for granular materials. It has proved difficult to discover a herbicide having a high level of activity against broadleaf perennial weeds when applied either as a foliar spray or in the granule form for soil treatment. The preferred environmental conditions for the successful introduction of a herbicide into the living plant system by these two methods vary widely, and consequently the desired characteristics for a compound to be efficient, via both modes of entry, calls for extreme versatility. A herbicide must have a number of essential characteristics to be suitable for applying to the soil, particularly when controlling deep-rooted difficult-to-kill woody weeds. It must be active at low concentrations, move readily through the soil to the root zone, be persistent both in the soil and plant tissue, and once inside the plant be readily translocated throughout the entire system. Picloram is one such herbicide which displays comparable activity when applied in the granule form or as a foliar spray.

This paper presents results of trials with picloram applied in the granular form on some of the more important woody weeds of New Zealand. Owing to the relatively slow knockdown by picloram and the strong resprout potential of certain species, up to 15 months may be required before final assessments can be made. Experience with picloram granules has shown that, where a high degree of knockdown has been obtained during a 4 to 6 month period, such satisfactory stem kill carries through to final resprout control. Provided the proportion of live plant tissue is not too high at this interim period, the degree of final kill can be expected to improve with time. These facts should be taken into account when considering results presented.

Two methods of application were used, namely, treatment of individual plants and broadcast application. For treatment of individual plants, granules were applied by hand over an area extending from the drip line inwards to the base, unless otherwise stated. Rates of application are expressed as grams of active 
ingredient per 6 in. basal diameter of the plant. Broadcast treatments were evenly applied by hand over a measured area with rates of application expressed as $\mathrm{lb}$ of active ingredient per acre. Ratings referred to are based on a 0 to 10 visual scale ( 10 being the maximum effect, 0 being the nil effect level); the values quoted are the means of the visual ratings of two or more persons.

\section{SWEET BRIER \\ (Rosa rubiginosa)}

Sweet brier has been a notoriously difficult weed to control with herbicides. Picloram was first evaluated on sweet brier in the spring of 1963, and subsequent results have shown it to be clearly the most active and effective chemical for the control of this weed. Field results to date from farmer usage of the chemical have substantiated those obtained in trials (Moffat, 1965). The following is a summary of the results of two trials conducted in Canterbury.

\section{TRIAL I}

This trial was laid down in October when the brier was still leafless but the leaf buds were just breaking. The standard basal treatment of 2,4,5-T ester in diesel was applied for comparison. The age of the bushes was estimated as between 3 and 6 years. Assessment was made 17 months after treatment (Table 1).

\section{TRIAL II}

This trial was also laid down in October when the brier was showing the first 2 to 3 true leaves following bud burst. The age of the bushes was estimated between 3 and 8 years. Assessments were made 5 months after treatment (Table 1).

TABLE 1: RATINGS OF SWEET BRIER REGROWTH SUPPRESSION

\begin{tabular}{|c|c|c|c|c|c|}
\hline Treatmen & $n t \underset{(l b}{B c}$ & $\begin{array}{l}\text { 3asal Spray } \\
\text { a.i./100 } \\
\text { gal) }\end{array}$ & $\begin{array}{l}\text { Grams a.i. } \\
\text { per 6 in. } \\
\text { basal diam. }\end{array}$ & $\begin{array}{l}\text { Regrowth } \\
\text { Trial I }\end{array}$ & $\begin{array}{c}\text { Suppression } \\
\text { Trial II }\end{array}$ \\
\hline $\begin{array}{l}2,4,5-\mathrm{T} \\
\text { (ester) }\end{array}$ & & \multirow[t]{5}{*}{10.0} & & 2.0 & - \\
\hline Picloram & $\ldots . \cdots \cdot$ & & 0.3 & - & 6.0 \\
\hline Picloram & ....... & & $0.6^{*}$ & 10.0 & 8.0 \\
\hline Picloram & ....... & & 1.2 & 10.0 & 10.0 \\
\hline Picloram & & & 2.4 & 9.5 & 10.0 \\
\hline
\end{tabular}

* Equivalent to $1 \mathrm{oz}$ of a $2 \% \mathrm{w} / \mathrm{w}$ granule.

In Trial I some grass clamage was noted in earlier inspections. However, this was of only a temporary nature, the sward being fully recovered at the last assessment. For Trial II the results presented are interim but the $0.6 \mathrm{~g}$ rate can be expected to improve to give a satisfactory final kill. The lowest rate is obviously a marginal dosage.

\section{GORSE}

(Ulex europaeus)

Undoubtedly gorse is the most widespread and major woody weed in New Zealand which generally requires repeat treatments of 2,4,5-T for a complete kill. Picloram applied to individual plants 
or as a broadcast treatment has given satisfactory control of gorse. A summary is given below of results of two trials, one in Wellington and one in Canterbury.

TRIAL I

Treatments of individual plants were made in September when the gorse was flowering and spring growth was just commencing. All bushes had been closely grazed by stock down to a height of 1 to $3 \mathrm{ft}$. The age of the bushes was estimated at 3 to 5 years. Ratings for regrowth suppression were made eight months after treatment (Table 2).

TRIAL II

Broadcast treatments were made in October when the gorse was flowering and soft spring growth was just evident. The height of the bushes ranged from $2 \mathrm{ft}$ to $5 \mathrm{ft}$, the age being estimated at 5 to 6 years. Ratings for regrowth suppression were made seven months after treatment (Table 2).

TABLE 2: RATINGS OF GORSE REGROWTH SUPPRESSION

\begin{tabular}{lccccc}
\hline & $\begin{array}{c}\text { Grams a.i. } \\
\text { per } 6 \text { in. } \\
\text { basal } \\
\text { diameter }\end{array}$ & lb a.i. per \\
Treatment & Trial I & Trial II \\
\hline Picloram & $\ldots . . .$. & 0.6 & 1.5 & 9.5 & 2.6 \\
Picloram & $\ldots . .$. & 1.2 & 3.0 & 9.5 & 6.0 \\
Picloram & $\ldots . . .$. & 2.4 & $6.0^{*}$ & 10.0 & 8.5 \\
Picloram & ...... & - & 12.0 & - & 8.6 \\
\hline
\end{tabular}

*Approximates $1 \mathrm{oz} / \mathrm{sq} . \mathrm{yd}$ of a $2 \% \mathrm{w} / \mathrm{w}$ formulation.

The initial knockdown of new growth and spines was almost as rapid as the standard 2,4,5-T foliar spray treatment. However stems did not completely brown off for three to five months, the speed depending on the rate of application. The slower rate of knockdown obtained in Trial II is most probably due to the drier conditions experienced on this site.

\section{BLACKBERRY}

(Rubus fruticosus complex)

Following the promising results obtained with a combination of picloram and 2,4.5-T as spray formulations on blackberry, particularly in areas where species semi-tolerant to 2,4,5-T exist, picloram granules have been evaluated for treating scattered infestations.

The following trial was conducted in Taranaki. Broadcast treatments were made in October on a dense, low-growing population. Active spring growth was just commencing with the first two to three true leaves present. Ratings for regrowth suppression were made six months after treatment (Table 3 ).

Results indicate that the $6 \mathrm{lb}$ rate and above will give satisfactory control. Although symptoms of picloram are still visible in the 
TABLE 3: RATINGS OF BLACKBERRY REGROWTH SUPPRESSION

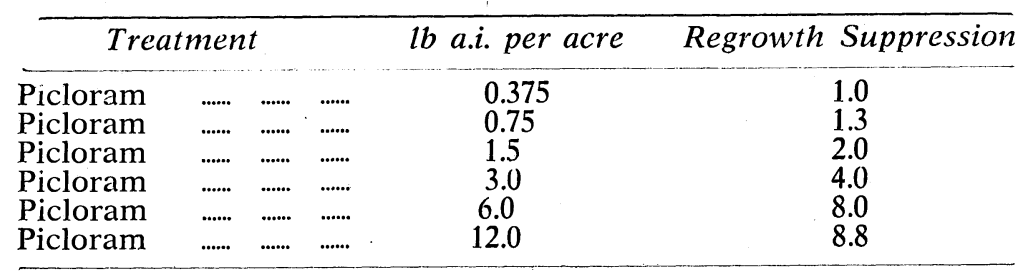

foliage of bushes treated at lower dosages, the majority are expected to recover. In other areas $3 \mathrm{lb}$ per acre has given an acceptable degrec of control.

\section{BROOM}

(Cytisus scoparius)

Picloram has shown outstanding activity against broom in both spray and granule form.

Results of two trials conducted in Canterbury arc given below. Broadcast treatments were applied in October when the broom on both sites was actively growing and flowering had commenced. On Trial I the broom foliage was extremely dense and only 1 to $2 \mathrm{ft}$ high owing to very hard grazing by stock. Ratings for regrowth suppression were made seven months after treatment (Table 4).

TABLE 4: RATINGS OF BROOM REGROWTH SUPPRESSION

\begin{tabular}{|c|c|c|c|c|c|}
\hline \multirow{2}{*}{\multicolumn{2}{|c|}{ Treatment }} & \multirow[b]{2}{*}{$l b$} & \multirow{2}{*}{ a.i. per acre } & \multicolumn{2}{|c|}{ Regrowth Suppressior } \\
\hline & & & & Trial I & Trial II \\
\hline Picloram & ........ & ....... & 0.75 & 5.3 & - \\
\hline Picloram & $\ldots . . .$. & ........ & 1.5 & 8.2 & 7.0 \\
\hline Picloram & ........ & ........ & 3.0 & 10.0 & 10.0 \\
\hline Picloram & ........ & ........ & 6.0 & 10.0 & 10.0 \\
\hline
\end{tabular}

The $1.5 \mathrm{lb}$ of picloram per acre is expected to improve to give a satisfactory degree of control whereas the $0.75 \mathrm{lb}$ rate appears a marginal dosage for mature bushes.

\section{RAGWORT}

(Senecio jabocaea)

Although ragwort cannot be classed as a woody weed, it is often difficult to control with 2,4-D, particularly once the flowering stage has been reached. Investigations have shown that ragwort is particularly susceptible to picloram at low rates of application. Results of one trial using picloram granules are given in Table 5 . At the time of treatment in October, plants varied from seedlings to the advanced rosette or "cabbage" stage with approximately 
$10 \%$ flowering. Only the largest plants were used for individual plant treatment. Ratings for final kill were made 15 weeks after treatment (Table 5).

TABLE 5: RATINGS FOR FINAL KILL OF RAGWORT

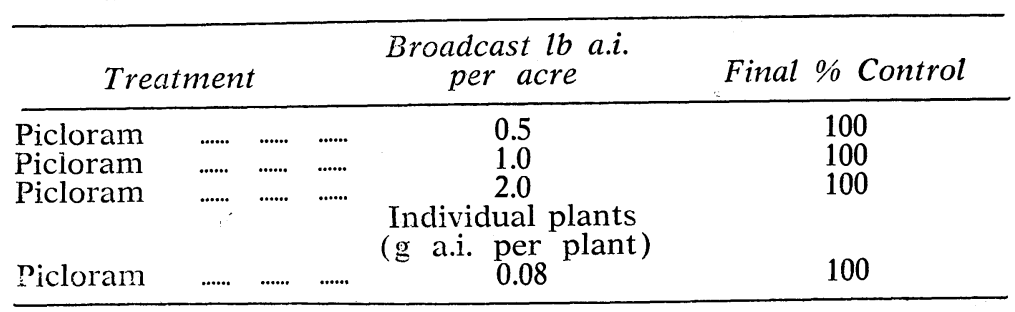

Complete weed control was obtained in all cases with a rapid collapse of the plant. Further studies are under way to determine the minimum dosage required for satisfactory control of ragwort under different stages of growth.

\section{EFFICIENCY OF GRANULAR APPLICATIONS}

Like foliar applied sprays, the main factors involved in obtaining the most efficient results with picloram granules are the rate, time and method of application.

Owing to the variability in growth form and size of the plant to be treated, some criteria are necessary for determining the rate of application. When treating individual scrub weeds that have a fairly upright growth form, such as sweet brier and broom, the most satisfactory measure used to date has been the basal diameter of the bushes. For species with a low spreading growth form, such as blackberry or dense populations of other weeds, which makes access around individual bushes difficult, application rates are best estimated on a plant coverage basis (oz/sq. yd).

Experience to date has indicated that the optimum time of application and the extent of this period varies widely according to local climatic conditions. In areas where cold winters and/or dry summers are normally experienced, granules should be applied from late winter to mid-spring for maximum efficiency. In areas where favourable conditions for plant growth and, in particular, root growth are experienced throughout most of the year, granules can be applied at any time apart from the mid-winter period. Results have been variable with mid-winter applications and further investigations are required to clarify this point.

For maximum results, granules should be applied evenly around the bush from the base out to the dripline. Apart from treatment of small plants, applications close to the base of the plant have been less effective than treatment around the dripline. When treating bushes on steep slopes, the bulk of the granules should be applied on the uphill side as some downward leaching will occur.

The use of efficient granular herbicides has a very definite place in a woody weed control programme. In situations where weeds are scattered over a wide area, where access is difficult for conventional spray gear, where there is a shortage of water or a potential spray drift hazard, granular formulations are the most cost efficient method of application. 


\section{CONCLUSIONS}

Gianular formulations of picloram have given a high degree of control of a number of difficult-to-kill perennial woody weeds. Trial results presented for sweet brier, blackberry, gorse, broom and ragwort indicate the activity of picloram when applied in granular form can be expected to at least equal that when it is applied as an overall spray. Other species such as inkweed (Phytolacca octandra), tutsan (Hypericum androsaemum), and tauhinu (Cassinia leptophylla) not mentioned in this paper have proved susceptible to picloram. Other species have shown various degrees of susceptibility to picloram granules but further investigations are required to establish conclusive results. Under certain conditions the use of granules is a more cost efficient method of applying a herbicide than the normal spray application. Further studies are under way to assess the performance of picloram granules on a wide range of problem broadleaf weeds under many soil types and climatic conditions.

\section{ACKNOWLEDGEMENTS}

The author is indebted to Dr G. W. Mason for assistance in the preparation of this paper and to staff of the Research and Development Department, Ivon Watkins-Dow Ltd., for assistance with the trials.

\section{REFERENCE}

Moffat, R. W., 1965: Proc. 18th N.Z. Weed \& Pest Control Conf.: 17. 